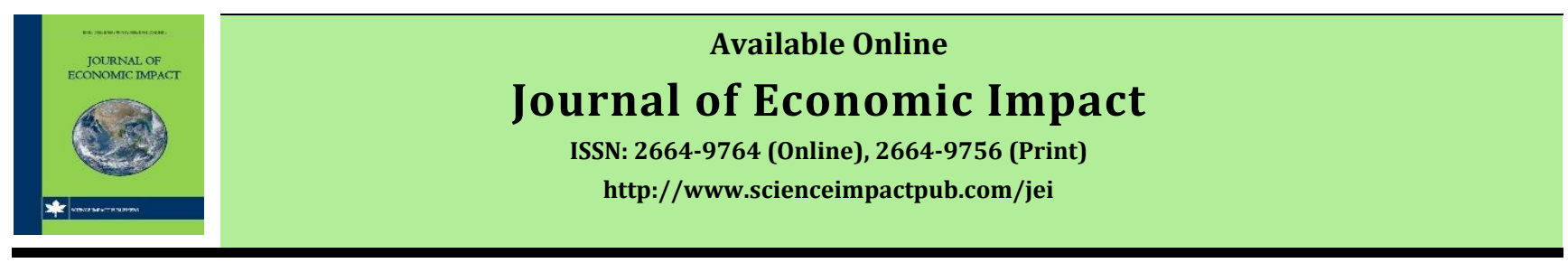

\title{
DETERMINANTS OF PRIVATE INVESTMENT IN PAKISTAN
}

\author{
Muhammad Suleman a, Abdur Rehman b,*, Haroon Javaid c \\ a Department of Economics, Gomal University D.I. Khan, KPK-Pakistan \\ ${ }^{b}$ Department of Agriculture Economics, Faculty of Agriculture, Gomal University D.I. Khan, KPK-Pakistan \\ ${ }^{c}$ Department of Business Administration, University of Sargodha, Pakistan
}

\section{ARTICLE INFO}

\section{Article history}

Received: November 28, 2020

Accepted: December 25, 2020

Published: December 28, 2020

\section{Keywords}

Determinants

Profitability

Private investment

Time-series data

Pakistan.

\section{ABSTRACT}

Private investment has a significant relation with the economic growth of the country. It plays an important role in reduction of unemployment and poverty by promoting efficiency and competition among the firms. This study is an attempt to investigate the determinants of private investment in Pakistan. For this purpose, time-series data is utilized for the period 1974-2013. The ARDL (Auto Regressive-Distributed Lag) modeling technique of co-integration was employed to estimate the short-run and long-run determinants of private investment in Pakistan. Empirical findings of this study indicated that in the short-run private investment in Pakistan is determined by the growth rate of GDP, public sector investment, and domestic savings. While in the long run it is determined by the official exchange rate, the growth rate of GDP, public sector investment, domestic savings, trade openness, and interest rate. The results also revealed that in the case of Pakistan different political regimes (democratic, non-democratic) have no significance in the determination of private investment. Stability tests of CUSUM and (CUSUMSQ) (Cumulative Sum Control Chart) were performed in this study. These tests indicated a stable, long run as well as short-run structural stability of the model.

\footnotetext{
* Corresponding Author: Abdur Rehman

Email:drrehmanagec@gu.edu.pk

(C) The Author(s) 2020.
}

\section{INTRODUCTION}

Investment means an addition to the stock of capital goods to produce more goods and generate more income. Investment may be of two kinds, it may be real investment or financial investment. The real investment is the expenditures on new buildings, new plants, new roads, new machines, and equipment or buying the shares of new firms. Real investment increases the productive capacity of the country. However, the financial investment decision means the buying of the stocks of existing companies or to make expenses to buy an already working plant.

A larger investment share from the private sector stimulates economic growth (Levine and Renelt, 1992). Ayeni and Kolade (2014) stated that the contribution of the private sector is larger than the public sector in the economic growth due to the fact that corruption appears to be at a lesser extent in the private sector as compared to the public sector. Many researchers argued that the share of investment from the private sector towards economic growth is greater as compared to the share of the public sector (Khan and Reinhart, 1990; Serven and Solimano, 1992). These researchers believed that the private sector is more productive and private firms have a very important role in the presence of investment and growth of nations in strengthening the structure of the country (World Bank, 2004).

Suryadarma and Suryahadi (2007) proposed three channels by which the private sector can be beneficial to the country. Firstly, the taxes paid to the government by the private sector can be further utilized for the provision of public services by the government. Secondly, capital expenditures such as structuring a new firm can be helpful for the new job creations. Thirdly, the private sector generates competition among the firms, which results in enhancement of productivity, raises 
profitability through improvement in the efficiency and thus will prompt decreased costs and that advantage goes to the general public. The investment theories are more helpful support to explain this research paper.

Classical economists were of the view that the rate of interest determines the level of investment. According to classical economists, there exists a negative relationship between the level of investment and the rate of interest. Keynes (1936) considered that investment relies on the marginal efficiency of capital and the interest rate. He considered that changes in income level will affect investment only in the long run. Accelerator theory of investment by Chenery (1952) says that when income enhances consequently investment will also enhance. Neoclassical theory of investment (Jorgenson, 1967 and 1971) claims that the rate of investment is determined by the speed with which firm adjust their stock towards the desired level of capital stock. Investment theory developed by Tobin (1969) stress was laid down on the ratio of the market value of existing capital and replacement cost of capital. In this theory, it was argued that the ratio of $Q$ is a stimulating force for investment. Where the ratio of $Q$ is equal to the existing capital/replacement cost of capital. Tobin's Q theory states that investors will make capital expenditures if $Q>1$ and they will decrease their capital expenditures if $Q<1$. Neoliberal theory of investment by McKinnon (1973) and Shaw (1973) consider the financial strength of a nation and the rate of interest are the key variables in explaining the investment behaviour of a country. This approach argued that a high rate of interest motivates the investment. This investment theory explains that the rising interest rates encourage domestic savings as a result of this amount of funds also increases in the economy (conduit effect), and greater availability of funds promotes the investment.

Majdzadeh et al. (2014) investigated 19 exogenous variables on investment from the private sector. The author applied Bayesian Model Averaging (BMA) technique and arrived at the conclusion that the most relevant determinants of private investment in Iran are imports of capital goods and the GDP growth rate. An application of the ARDL model by Khalid (2014) on the data from Pakistan economy suggested that an improvement in the growth rate of GDP, credit availability for the private sector, and exchange rate contributes positively towards the level of private investment. The study also reported a significant negative impact of debt servicing on the private sector investment.

Hamuda et al. (2013) applied the ARDL technique on time series data for the period 1961-2011 for the Tunisian economy and had drawn the conclusion that the monetary base of the country had a strong association with domestic investment. Sharafat (2013) utilized time series data over the period 1972-2011 to examine the factors affecting longrun investment function in Pakistan. Their results reported the positive connection between private investment in its various determinants namely inflation rate and debt servicing. While they pointed out a positive association between GDP growth rate, rate of exchange, and debt servicing. AlKhatib et al. (2011) carried a work for the economy of Jordan on the time series data for the time span 1980-2010. The ARDL approach is used in the study to determine the coefficients of domestic investment. They established that GDP growth rate and exports as a ratio of GDP contributes positively towards investment in both the long run and short run. They also evidenced that Foreign Direct Investment as a ratio of GDP and financial intermediation (M2/GDP) boost the domestic investment only in the short run.

Haroon and Nasr (2011) attempted to evaluate the determinants of private investment in Pakistan over the period 1986-2007. The authors determine that private investment is positively associated with subsidies, domestic savings, and public sector outlay and negatively associated with debt services and indirect taxes. The study of Salahuddin et al. (2009) was done on the panel data of 21 Muslim countries they applied the GMM method for the time period 1970-2002 and reported the existence of positive and strong co-integration between real GDP growth rate, domestic saving, trade openness and institutional progress and negative effect of foreign debt servicing in the private investment. Bhatti et al. (2008) carried out a study in Pakistan they examine the effect of democracy, political, and policy uncertainty. By utilizing the Engel-Granger methodology they revealed that private sector investment is negatively related to political and policy uncertainties in the country. They also showed an insignificant effect of democracy on private investment. Khan and Khan (2007) examined the short-run and longrun coefficients of private investment in Pakistan they utilized the time series data for the time span 1972-2005, applied the approach of ARDL, and discussed that in Pakistan private investment is stimulated due to the existence of accelerator principal and it is adversely affected due to the crowding out principal. Acosta and Loza (2005) conducted a study in Argentina for the three decades 19702000 to find out the short-run and long-run determinants of private investment. They applied the co-integration technique of Engle and Granger and concluded that in the short run private investment is determined by trade openness, rate of exchange, and aggregate demand. The long-run results of the study showed that determinants of private investment are well developed financial and credit market and sustain budget performance. 


\section{METHODOLOGY}

\section{Data and Data Sources}

The study is based on time-series data. Time series data for the period 1974-2013 were used in the study to determine the short-run and long-run impact of different factors on private investment in the country. The data is collected from the World Bank data source.

\section{Econometric Model}

The following econometrics form of the equation is used to estimate the coefficient of various factors expected to influence private investment.

Log prinvt $=\alpha+\beta 1 \operatorname{logrexrt}+\beta 2 \operatorname{logrealgdpt}+\beta 3 \log p u b i n v t$

$+\beta 4$ logrirt $+\beta$ logsavingt $+\beta 6$ logtradet $+\beta 7$ dummy $+\varepsilon$

Where as

logprinvt $\quad=\quad$ Log of private investment

logrexrt $\quad=\quad$ Log of official exchange rate

logrealgdpt $\quad=\quad$ Log growth rate GDP

logpubinvt $\quad=\quad$ Log of public sector investment

logrirt $\quad=\quad$ Log of interest rate

logsavingt $\quad=\quad$ Log of domestic saving

logtradet $\quad=\quad$ Log of trade openness

Dummy = Dummy variable

$1=$ democratic regimes, $0=$ non democratic regimes

$\varepsilon \quad=\quad$ Error term

$\mathrm{t} \quad=\quad$ Time trend

Before estimating the coefficients of the model it is necessary to investigate the stationary property of the variables. This reason behind this stationary check is to avoid the spurious and unreliable results of the model. The null hypothesis for the ADF test is that;

$\mathrm{H} 0=$ series is non-stationary.

Against the alternative hypothesis of

$\mathrm{H} 1$ = Series is stationary.

Table 1. Result of ADF test.

\begin{tabular}{|c|c|c|c|c|c|}
\hline \multirow[b]{2}{*}{ Variables } & \multicolumn{2}{|c|}{ ADLF Statistic at Level } & \multicolumn{2}{|c|}{ ADF Statistic at First Difference } & \multirow[b]{2}{*}{$\begin{array}{c}\text { Order of } \\
\text { integration }\end{array}$} \\
\hline & Intercept only & $\begin{array}{l}\text { Trend and } \\
\text { intercept }\end{array}$ & Intercept only & $\begin{array}{c}\text { Trend and } \\
\text { intercept }\end{array}$ & \\
\hline $\log ($ exrt $)$ & -1.714675 & -1.530618 & $7.212326^{* * *}$ & $-7.198450 * * *$ & $\mathrm{I}(1)$ \\
\hline $\log ($ real gdpt) & $5.043831^{* *}$ & $-4.932028^{* *}$ & & & $\mathrm{I}(0)$ \\
\hline $\log ($ publinvt $)$ & -2.909671 & -2.865175 & $6.649182^{* * *}$ & $-6.651110^{* * *}$ & $\mathrm{I}(\mathrm{I})$ \\
\hline $\log ($ rirt $)$ & 2.526137 & 2.474244 & $5.414185^{* * *}$ & $5.348604^{* * *}$ & $\mathrm{I}(1)$ \\
\hline $\log ($ saving $\mathrm{t})$ & -2.484735 & -3.830398 & $4.797392^{* * *}$ & $-4.756252^{* * *}$ & $\mathrm{I}(1)$ \\
\hline $\log$ (tradet) & -1.714675 & -1.530618 & $7.212326^{* * *}$ & $-7.198450^{* * *}$ & $\mathrm{I}(1)$ \\
\hline $\log ($ prinvt $)$ & -1.791181 & -1.982289 & $7.604650 * * *$ & $-7.793061^{* * *}$ & $\mathrm{I}(1)$ \\
\hline
\end{tabular}

Source: Researcher's own calculations.

The results of the selected model ARDL model $(1,1,3,2,2$, 0,0 ) are given in Table 2 . Table 2 shows the selection of lags by AIC criteria. The value of the coefficient of determination
Auto Regressive Distributed Lags (ARDL) approach is applied for the long run and short run coefficients of the model.

$+\beta 8$ Dummy $+\lambda 1 \Delta$ logprinvt- $1+\lambda 2 \Delta$ logrexrtt-

$1+\lambda 3 \Delta$ logrealgdpt $-1+\lambda 4 \Delta$ logpubinvt $-1+\lambda 5 \Delta$ logrirt $-1+$ $\lambda 6 \Delta$ logsavingt $-1+\lambda 7 \Delta$ logtradet $-1+\lambda 8$ Dummy $+\omega$ ECT $t-1+$ $\varepsilon \mathrm{t}$

$\alpha \quad=$ Constant

$\mathrm{q}=$ Maximum lag order

$\beta 1 \ldots \beta 8=$ Short run coefficients (error correction dynamics)

$\lambda 1 \ldots . . \lambda 8=$ Correspond to long run relationship

$\omega \quad=$ Speed of adjustment

$\mathrm{t} \quad=$ Time trend

$\varepsilon \mathrm{t} \quad=$ Error term

Bound test is applied to investigate the existence of long run relationship among the variables. The general form of the hypotheses for the F-statistic test is given below.

$\mathrm{HO}$ :

$\lambda \operatorname{logprinv}=\lambda \log r e x r=\lambda \log r e a l g d p=\lambda \log p u b i n v=\lambda \log r i r=\lambda l$ ogsaving $=\lambda \log$ trade $=0$

H1:

$\lambda \operatorname{logprinv} \neq \lambda \log r e x r \neq \lambda \operatorname{logrealgdp} \neq \lambda \log p u b i n v \neq \lambda \log r i r \neq \lambda l$ ogsaving $\neq \lambda$ logtrade $\neq 0$

\section{RESULTS AND DISCUSSION}

\section{Result of Augmented Dicky Fuller Test}

The result of the Augmented Dicky Fuller Test are shown in Table 1. The null hypothesis is that the series is nonstationary. $* * *, * *, *$ denotes the rejection of the null hypothesis of non-stationary at the $1 \%, 5 \%$, and $10 \%$ significance levels. The results of the ADF test show that the log of real GDP is stationary at a level i.e. I (0). Whereas all the other variables are non-stationary at level but they went stationary after the first difference i.e. I (1).
R-Squared is 0.954 which is showing that $95 \%$ of the variation in our dependent variable (private investment) is explained by explanatory variables included in the model. 
The probability value of the F-statistic is also indicating a significant sign which is an indication of the overall significance of the model. The null hypothesis of no co- integration is rejected and we accept the alternative hypothesis of long-run co-integration among the variables. The results of bound test is given in Table 3 .

Table 2. Lag selection.

\begin{tabular}{lllll}
\hline Variable & Coefficient & Std. Error & t-Statistic & Prob.* $^{*}$ \\
\hline prinv(-1) & 0.181853 & 0.156885 & 1.159150 & 0.2600 \\
exr & -0.170598 & 0.218601 & -0.780407 & 0.4443 \\
exr(-1) & 0.431272 & 0.180504 & 2.389262 & 0.0268 \\
real gdp & -0.024711 & 0.033048 & -0.747720 & 0.4633 \\
Real gdp(-1) & 0.030472 & 0.031410 & 0.970133 & 0.3436 \\
real gdp(-2) & 0.115958 & 0.032756 & 3.540082 & 0.0021 \\
Real gdp(-3) & 0.064153 & 0.023122 & 2.774521 & 0.0117 \\
pubinv & 0.990271 & 0.456356 & 2.169955 & 0.0422 \\
pubinv(-1) & -0.722504 & 0.277357 & -2.604957 & 0.0169 \\
pubinv(-2) & -0.137331 & 0.053524 & -2.565781 & 0.0184 \\
rir & -0.019214 & 0.072368 & -0.265499 & 0.7933 \\
rir(-1) & 0.015129 & 0.066741 & 0.226684 & 0.8230 \\
rir(-2) & 0.084657 & 0.061798 & 1.369907 & 0.1859 \\
saving & 0.144139 & 0.058183 & 2.477347 & 0.0223 \\
trade & 0.015111 & 0.255105 & 0.059235 & 0.9534 \\
dummy & -0.067637 & 0.039634 & -1.706560 & 0.1034 \\
C & -0.363097 & 0.782908 & -0.463780 & 0.6478 \\
\hline
\end{tabular}

Table 3. Results of bound test.

\begin{tabular}{lll}
\hline Critical Values & Upper bound value & Lower bound value \\
\hline $10 \%$ & 2.94 & 1.99 \\
$5 \%$ & 3.28 & 2.27 \\
$1 \%$ & 3.99 & 2.88 \\
\hline
\end{tabular}

Source: Researcher's own calculations, F-Statistics=5.488609.

\section{Results of the Short-run Model}

The estimated value of the coefficient of GDP showed that there exists an accelerator theory of investment in Pakistan in the short run. As the accelerator theory also claims a positive association between GDP growth and the rate of investment. It indicates that improvement in the GDP growth rate stimulates the level of private investment in Pakistan in the short run. The estimated value of the coefficient is 0.053636 which shows that an increase in the GDP growth rate by one unit increases the rate of private investment by 0.053636 units. The coefficient of public sector investment is significant in the short run and has a positive sign. The estimated value shows that a one-unit lift in the public sector investment brings an improvement in the private sector investment by 0.779829 units. This phenomenon depicts the crowding in the pattern of public sector investment in Pakistan.

This is the indication that expenditures from the public sector raise the demand for goods. When the demand for goods is high, private sector spending increases. One other aspect of the positive relationship between private investment and public sector investment is that as the government makes expenditures to develop the infrastructure of the country, the private sector gets encouragement from the developed infrastructure, and as a consequence private sector investment increases. The coefficient of domestic saving is also significant in the short run estimated value of the coefficient is 0.13441 which shows that increase in domestic saving by one unit in the short run enhances the rate of private investment by 0.13441 units in Pakistan. This pattern depicts that Savings, therefore, impact positively on investment. While all other variables are proved to be insignificant determinants of the private investment in the short run. The value of ECT is -0.81756 with a highly significant p-value as shown in Table 4 . This value shows the speed of adjustment from short-run disequilibrium to longrun equilibrium. Here it reports that any disequilibrium in the short run is adjusted and converges toward the long-run equilibrium with the speed of $81.756 \%$. 
Table 4. Results of short run model.

\begin{tabular}{lllll}
\hline Variable & Coefficient & Std. Error & t-Statistic & Prob. \\
\hline D(log exr) & 0.30253 & 0.16936 & 1.7863 & 0.084 \\
D(log real gdp) & 0.053636 & 0.023605 & 2.272207 & 0.0319 \\
D(log pubinv) & 0.779829 & 0.176263 & 4.424239 & 0.0002 \\
D(log rir) & 0.09848 & 0.10685 & 0.9216 & 0.367 \\
D(log saving) & 0.13441 & 0.046918 & 2.8649 & 0.009 \\
D(log trade) & 0.22721 & 0.223904 & 1.0147 & 0.322 \\
dummy & -0.02054 & 0.035335 & -0.5815 & 0.567 \\
ECT(-1) & -0.81756 & 0.089437 & -9.1412 & 0.000 \\
\hline
\end{tabular}

\section{Results of the Long-run Model}

The coefficient of the exchange rate is significant and has an estimated value of 0.31861 as shown in Table 5. It means that a 1 unit increase in the exchange rate will stimulate private investment by 0.31861 units in Pakistan. This result indicates that a devaluation of the Pakistani currency encourages private investment in Pakistan. Because of the fact devaluation will make Pakistani products inexpensive and attractive to foreign countries. While products from other countries (imports) will be expensive and unattractive for Pakistanis. As result of this devaluation motivate the private investment in Pakistan. The positive and significant coefficient of exchange rate depicts the export-led growth nature of economy in case of Pakistan.

Table 5. Results of the long run model.

\begin{tabular}{lllll}
\hline Variable & Coefficient & Std. Error & t-Statistic & Prob. \\
\hline $\log ($ exr) & 0.31861 & 0.04036 & 7.8926 & 0.000 \\
$\log ($ real gdp) & 0.22718 & 0.09097 & 2.4971 & 0.021 \\
$\log$ (pubinv) & 0.14471 & 0.030843 & 4.6918 & 0.000 \\
$\log$ (rir) & -0.09553 & 0.038338 & -2.4919 & 0.021 \\
$\log ($ saving) & 0.17617 & 0.07546 & 2.3345 & 0.030 \\
$\log ($ trade) & 0.154339 & 0.062439 & 2.471822 & 0.0206 \\
dummy & -0.08267 & 0.04473 & -1.8479 & 0.079 \\
C & -0.44380 & 0.92052 & -0.4821 & 0.635 \\
\hline
\end{tabular}

The coefficient of GDP has a significant estimated value of 0.22718 ; it means that a 1 unit increase in the GDP increases the private investment by 0.22718 units. This result confirms the accelerator investment theory in Pakistan. The estimated coefficient of public investment has a significant value of 0.14471 . It suggests that if investment from the public sector were to increase by one unit, consequently private investment will also increase by 0.14471 units. This situation suggests the crowding in private investment by public sector investment. These results depict that private sector investment is encouraged by the public sector investment both in the long run as well as in the short run. The result indicates that the estimated value of the coefficient of the rate of interest is -0.09553 and it is significant with a negative sign in the long run. It means that there is a negative relationship between the rate of interest and private investment in the long run. This indicates an improvement in the rate of interest by one unit brings down the rate of private investment by 0.09553 units in Pakistan. Thus in the case of Pakistan Mckinnon and Shaw's hypothesis is rejected. And the classical economist's views are accepted that claims a negative connection between the rate of interest and the investment. The estimated coefficient of domestic savings has a significant value of 0.17617 . This means that in the long run there is a positive association between the rate of savings and private investment. The estimated value shows that as the domestic saving increase by one unit, the rate of private investment increases by 0.17617 units.

According to the obtained results, it is cleared that the coefficient of trade openness is a significant determinant of private investment for Pakistan in the long run. The estimated value of the coefficient for trade openness is 0.154339 . It means that a one-unit increase in the rate of trade openness stimulates the level of private investment by 0.154339 units. This indicates the importance of trade openness for boosting private investment via encouraging 
exports and importing capital goods and the latest technology, which motivates the investment in the country. The result of the dummy variable is insignificant; it means that differences in political regimes have not played any role to determine the rate of private investment in Pakistan. The results of diagnostic tests are shown in Table 6.

Table 6. Results of diagnostic tests.

\begin{tabular}{|c|c|c|c|c|c|}
\hline Problem & Test name & Hypothesis & F-Statistic & P-Value & Decision \\
\hline Hetroscedasticity & $\begin{array}{l}\text { Breusch Pagan-Godfrey } \\
\text { Hetrosckedasticity test }\end{array}$ & $\begin{array}{l}\mathrm{H} 0=\text { residuals are homoskedastic } \\
\mathrm{H} 1 \quad=\text { residuals are } \\
\text { heteroskedastic }\end{array}$ & 1.0388 & 0.4547 & Accepted \\
\hline Autocorrelation & $\begin{array}{l}\text { Breusch-Godfrey Serial } \\
\text { Correlation test }\end{array}$ & $\begin{array}{l}\mathrm{H} 0=\text { no autocorrelation exists } \\
\mathrm{H} 1=\text { autocorrelation exists }\end{array}$ & 0.2897 & 0.1516 & Accepted \\
\hline Specification error & $\begin{array}{l}\text { Ramsey RESET test for } \\
\text { Model specification }\end{array}$ & $\begin{array}{l}\mathrm{H} 0=\text { correct specification of } \\
\text { model } \\
\mathrm{H} 1=\text { incorrect specification of } \\
\text { model }\end{array}$ & 3.0970 & 0.0930 & Accepted \\
\hline $\begin{array}{l}\text { Normality of } \\
\text { residuals }\end{array}$ & $\begin{array}{l}\text { Jarque-Bera Normality } \\
\text { test }\end{array}$ & $\begin{array}{l}\mathrm{H} 0=\text { residuals are normal } \\
\mathrm{H} 1=\text { residuals are not normal }\end{array}$ & 3.2674 & 0.195204 & Accepted \\
\hline
\end{tabular}
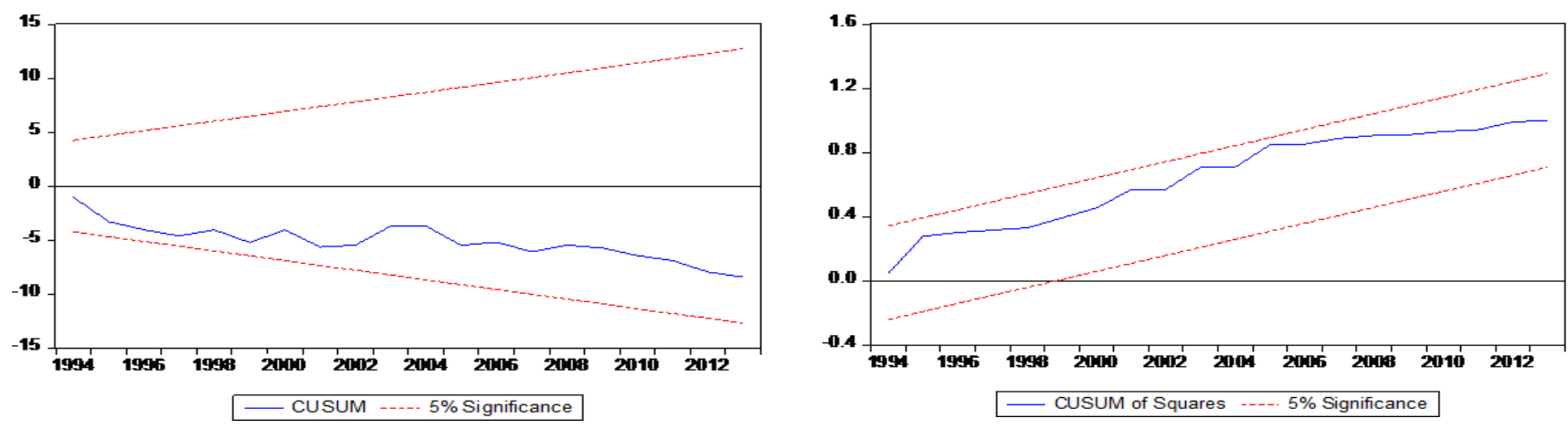

Figure 1. Plot of CUSUM.

\section{Stability Test}

Brown et al. (1975) proposed a test to examine the structural stability of the long-run and short-run relationship for the entire time span under study. This test is called the cumulative sum (CUSUM) and the cumulative sum of squares (CUSUMSQ) of the recursive residual test. Figure 1 reveals that the blue lines of CUSUM and CUSUMSQ remain inside at the red lines of a $5 \%$ level of significance. Hence the model selected in this study is correctly specified and stable in the long run as well as in the short run.

This study is conducted to determine the factor which can significantly affect the level of private investment in Pakistan. To estimate the coefficients of the model we used time-series data and applied the ARDL model.

\section{CONCLUSIONS}

In the long run, devaluating the currency encourages private sector investment in Pakistan by making our domestically produced goods (exports) inexpensive for other countries. While the coefficient of the exchange rate is proved to be an insignificant determinant in the short run. Our results also provide support for the accelerator principle and crowding in the hypothesis in the case of Pakistan for both the long run as well as in the short run. It is found that in the long run the level of private investment is positively determined by GDP growth rate and the public sector investment. However, in the long-run case, we reject the McKinnon-Shaw hypothesis and accept the classical principle of investment because the rate of interest and the private sector investment are negatively related. Our study also reported a positive association between the rate of private investment and domestic savings in both cases whether it is a long run or short run. Whereas it found that trade openness stimulates the private sector investment in the long run only. The different government regimes have not any significant contribution to the level of private investment in Pakistan in the long run and short run cases. The positive linkage between the rate of exchange and the private sector investment indicates the export-oriented economy of Pakistan. So the policies to enhance the exchange rate will boost the domestic private sector. As it is clear that the GDP growth rate has a positive contribution to the rate of private sector investment in Pakistan. Thus it is essential for the government to put strong efforts to promote the economic growth rate. A boost in the economic growth rate would be a very substantial policy step to raise the private sector 
investment. It is important for the government to make the investment expenditures for the provision of financial physical and technological infrastructure to offer a business friendly environment and to further crowd in private sector investment. The decline in the public sector expenditures would further worsen the private sector investment. Private sector investment is attracted by the decline in the rate of interest as suggested by the results. To appeal the investment from the private sector a policy measure of expending money supply by lowering interest rate (expansionary monetary policy) might stimulate private sector investment by encouraging the borrowing by the investors. The results of the study suggest that an improvement in domestic savings improves the rate of private investment in Pakistan. It is suggested to the government to put great endeavor to promote the rate of domestic savings in the country. Implementation of trade promotion measures might be a very significant tool to further promote the private sector investment.

\section{REFERENCES}

Acosta, P., Loza, A., 2005. Short and long run determinants of private investment in Argentina. Journal of Applied Economics, 8(2), 389-406.

Alkhatib, H.B., Altaleb, G.S., Alokor, S.M., 2011. Economical determinants of domestic investment, European Scientific Journal, 8(7), 1-17.

Ayeni \& Kolade, R. (2014). Macroeconomic determinants of private sector investment-an ARDL approach: evidence from Nigeria. Global Advanced Research Journal of Management and Business Studies, 3(2), 082-089.

Bhatti, M.A., Muhammad, A.A., Iqbal, W., 2008. Impact of democracy, political instability and policy uncertainty on private investment: A case study of Pakistan. Forman Journal of Economic Studies, (4), 87-101.

Brown, R.L., Durbin, J., Evans, J.M., 1975. Techniques for testing the constancy of regression relations over time. Journal of the Royal Statistical Society, 37, 149-192.

Chenery, H., 1952. Overcapacity and the accelerator principle. Econometrica, 20, 1-28.

Hamuda, A., Šuliková, V., Gazda, V., Horváth, D., 2013. ARDL investment model of Tunisia. Theoretical and Applied Economics Volume, 20(2), 57-68.

Haroon, M., Nasr, M., 2011. Role of private investment in economic development of Pakistan. International Review of Business Research Paper, 7(1), 420-439.
Jorgenson, D.W., 1967. The Theory of investment behavior, in R. Ferber (ed), Determinants of Investment Behavior, N.B.E.R.

Jorgenson, D.W., 1971. Econometric studies of investment behaviour: A survey. Journal of Economic literature, 9(4), 111-1147.

Keynes, M.J., 1936. The general theory of employment, interest, and money. New York, Harcourt Brace Jovanovich, reprinted, 1953.

Khalid, A., 2014. It is significant determinants of private investment: A case study of Pakistan (1972-2013). Middle East Journal of Scientific Research, 22(3), 495-500.

Khan, M.S., Reinhardt, C.M., 1990. Private investment and economic growth in developing countries. World Development, 8(1), 19-27.

Khan, S., Khan, A., 2007. What determines private investment? The case of Pakistan" PIDE Working Papers, 2007:36. Pakistan Institute of Development Economics, Islamabad.

Levine, R., Renelt, D., 1992. A sensitivity analysis of crosscountry regressions. American Economic Review, 82(4), 942-963.

Majdzadeh, M.A., Ghazanfari, A., Ara, M.M., 2014. Determinants of private investment in Iran based on Bayesian Model Averaging. International Journal of Academic Research in Business and Social Sciences, 4(7), 229-240.

McKinnon, R.I., 1973. Money and credit in economic development. Washington DC: The Brookings Institution.

Salahuddin, M., Salim, A., Islam, R., 2009. Determinants of investment in Muslim developing countries: An empirical investigation. Int. Journal of Economics and Management, 3(1), 100-129.

Serven, L., Solimono, A., 1992. Private Investment and macroeconomic adjustment: A Survey, World Bank Research Observer, 7(1), 95-114.

Sharafat, A., 2013. A Co integration approach to estimate private investment demand function of Pakistan. Asian Journal of Research in Business Economics and Management, 3(9), 1-13.

Shaw, E.S., 1973. Financial deeping in economic development. New York: Oxford University Press.

Suryadarma, D., Suryahadi, A., 2007. The impact of private sector growth on poverty reduction: Evidence from Indonesia. SMERU Working Paper. Jakarta: SMERU Research Institute.

Tobin, J. 1969. A general equilibrium approach to monetary theory. Journal of Money, Credit and Banking, 1(1), 1529.

World Bank, 2004. A better investment climate for everyone, World Bank and Oxford University Press, Washington DC.

Publisher's note: Science Impact Publishers remain neutral with regard to jurisdictional claims in published maps and institutional affiliations.

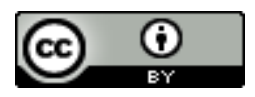

Open Access This article is licensed under a Creative Commons Attribution 4.0 International License, which permits use, sharing, adaptation, distribution and reproduction in any medium or format, as long as you give appropriate credit to the original author(s) and the source, provide a link to the Creative Commons license and indicate if changes were made. The images or other third-party material in this article are included in the article's Creative Commons license, unless indicated otherwise in a credit line to the material. If material is not included in the article's Creative Commons license and your intended use is not permitted by statutory regulation or exceeds the permitted use, you will need to obtain permission directly from the copyright holder. To view a copy of this license, visit https://creativecommons.org/licenses/by/4.0/.

The Author(s) 2020. 